Article

\title{
Spatio-Temporal Modeling of the Urban Heat Island in the Phoenix Metropolitan Area: Land Use Change Implications
}

\author{
Chuyuan Wang ${ }^{1, *}$, Soe W. Myint ${ }^{1}$, Zhihua Wang ${ }^{2}$ and Jiyun Song ${ }^{2}$ \\ 1 School of Geographical Sciences and Urban Planning, Arizona State University, Tempe, AZ 85287, USA; \\ Soe.Myint@asu.edu \\ 2 School of Sustainable Engineering and the Built Environment, Arizona State University, Tempe, AZ 85287, \\ USA; zhwang@asu.edu (Z.W.); jsong52@asu.edu (J.S.) \\ * Correspondence: chuyuanw@asu.edu; Tel.: +1-480-965-7533
}

Academic Editors: Richard Müller and Prasad S. Thenkabail

Received: 3 January 2016; Accepted: 18 February 2016; Published: 26 February 2016

\begin{abstract}
This study examines the spatial and temporal patterns of the surface urban heat island (SUHI) intensity in the Phoenix metropolitan area and the relationship with land use land cover (LULC) change between 2000 and 2014. The objective is to identify specific regions in Phoenix that have been increasingly heated and cooled to further understand how LULC change influences the SUHI intensity. The data employed include MODerate-resolution Imaging Spectroradiometer (MODIS) land surface temperature (LST) 8-day composite June imagery, and classified LULC maps generated using 2000 and 2014 Landsat imagery. Results show that the regions that experienced the most significant LST changes during the study period are primarily on the outskirts of the Phoenix metropolitan area for both daytime and nighttime. The conversion to urban, residential, and impervious surfaces from all other LULC types has been identified as the primary cause of the UHI effect in Phoenix. Vegetation cover has been shown to significantly lower LST for both daytime and nighttime due to its strong cooling effect by producing more latent heat flux and less sensible heat flux. We suggest that urban planners, decision-makers, and city managers formulate new policies and regulations that encourage residential, commercial, and industrial developers to include more vegetation when planning new construction.
\end{abstract}

Keywords: urban heat island; spatio-temporal pattern; land surface temperature; land use land cover change; urbanization

\section{Introduction}

The greater Phoenix metropolitan area in the State of Arizona has a subtropical desert climate that makes it one of the warmest cities in the United States. It also has the most significant urban climate effects in the world [1]. Despite the excessive heat in the summer, Phoenix ranks among the fastest growing cities in the United States. The increasing population has resulted in rapid urban expansion in the past few decades. Concomitant with this rapid rate of urbanization, the urban heat island (UHI) phenomenon has been exacerbated. UHI has been linked, among many adverse environmental impacts, with increased energy consumption [2,3] and water use [4,5]; compromised human health and comfort [6]; and downgraded air quality $[7,8]$. These issues have become increasingly prominent in Phoenix.

The UHI effect has been extensively studied for the Phoenix metropolitan area. For example, the UHI spatial and temporal properties for the summer between 1949 and 1985 were investigated 
using air temperature data collected from local weather stations [5,9]. It was found that summer temperatures were the highest in central Phoenix and were rising most rapidly in the downtown area, while temperatures were decreasing outside of the city [9]. Urban development and expansion, especially housing development, was the primary contributor of the Phoenix UHI effect from 1990 to $2004[5,10]$. The usage of air temperature data collected from a limited amount of local weather stations in these studies, however, has restrictions because these data are not continuous. Therefore, the spatial temperature trends for the entire metropolitan area cannot be adequately quantified in this case. For this reason, some scientists have turned to the use of remotely-sensed data for UHI analysis. The surface urban heat island (SUHI) effect is observed by using remotely-sensed thermal infrared data, such as Landsat and ASTER satellite thermal infrared data, which allow the retrieval of land surface temperature (LST) [11-15]. The relationship between detailed land use land cover (LULC) types and LST derived from ASTER imagery was studied by Myint $e t$ al. [16]. It has been discovered that dark impervious surfaces, rather than buildings in the city, are primarily responsible for extreme heat in Phoenix [16]. This finding has also been confirmed by Imhoff et al. [17]. Zheng et al. examined the effects of spatial configuration of paved surfaces on LST in Phoenix urban area using local Moran's I and suggested that aggregate warming effects were mainly contributed by clustered paved surfaces [18]. On the other hand, it has been found that increasing irrigated landscape can lower nighttime temperatures [19], which can be a possible UHI mitigation strategy to prevent daytime heat storage and help lower LST. This strategy, however, requires a significant amount of water that is very scarce in a desert city. Using cool and reflective materials has become an effective strategy to mitigate the UHI effect in the urban built environment [20-23]. However, it is recommended that this strategy needs to be determined on a city-by-city basis because the mitigation potential of those materials depends on different urban environmental factors [24].

Although metropolitan Phoenix's UHI effect has been well studied, much of the literature neglects the area's long-term spatio-temporal pattern of SUHI intensity and its relationship with LULC change. It is necessary to identify regions that are being increasingly heated and cooled in order to further understand how LULC change influences the SUHI effect. The main objective of this study is to examine which regions within the Phoenix metropolitan area have experienced statistically significant LST increases and decreases compared to surrounding non-urbanized areas for both daytime and nighttime. In addition, this research explores the relationship between LULC change and urban LST variations in Phoenix.

\section{Study Area}

The Phoenix metropolitan area is located in central Arizona, USA, and is the sixth largest U.S. city, with an estimated population of 4.4 million [25], encompassing a total area of approximately $2800 \mathrm{~km}^{2}$ (Figure 1). It is located in the northeast part of the Sonoran Desert and receives an average annual precipitation of $204 \mathrm{~mm}$ (8.03 in.) [26]. The daily high temperature exceeds $37.8{ }^{\circ} \mathrm{C}$ $\left(100{ }^{\circ} \mathrm{F}\right)$ for an average of 110 days every year, which normally occurs from late May until early September. The highest temperature can reach more than $43.3^{\circ} \mathrm{C}\left(110^{\circ} \mathrm{F}\right)$ for an annual average of 18 days. The study area has diverse LULC types, including commercial, industrial, residential areas, undisturbed desert, agriculture, grassland, and water bodies. 


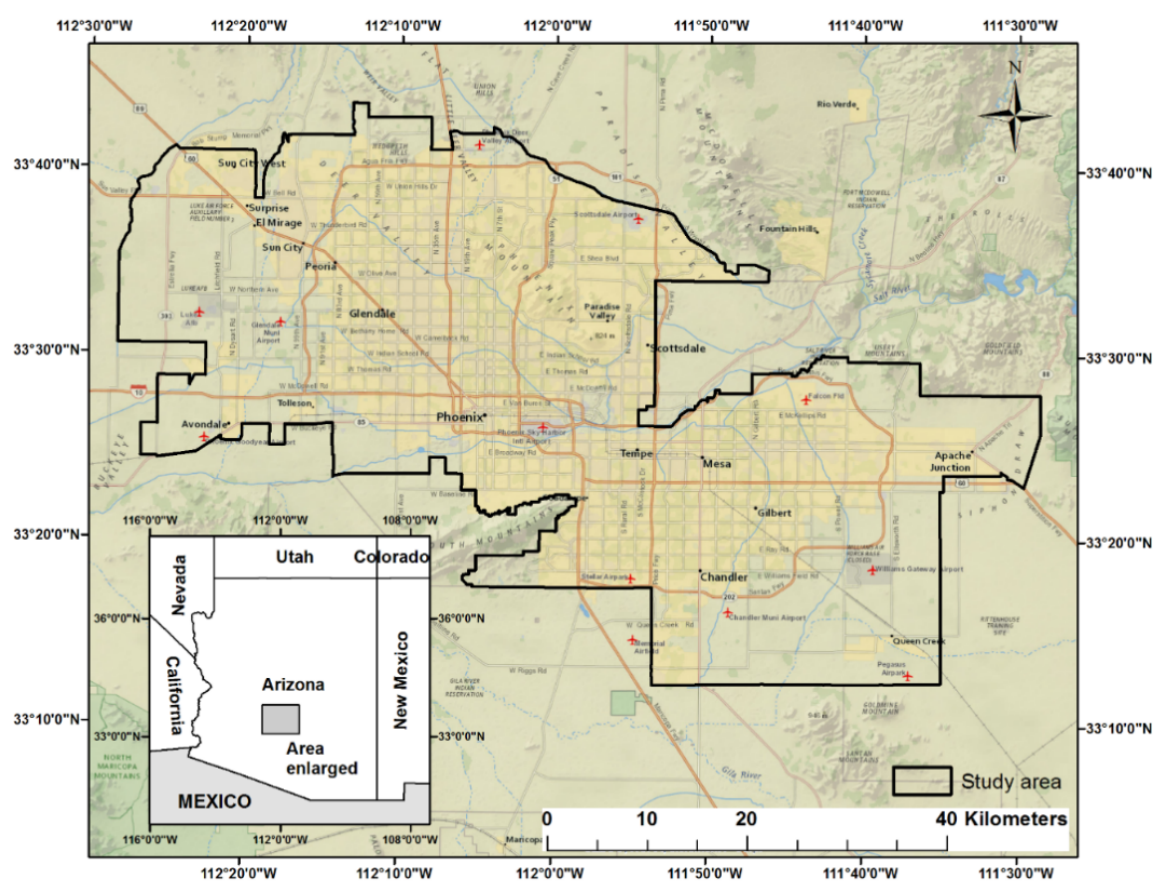

Figure 1. Map of study area.

\section{Data and Methods}

\subsection{Data}

Satellite remote sensing offers a great opportunity to acquire continuous LST data without direct physical contact with the surface, with sufficient spatial resolution to distinguish between urban and surrounding rural areas. The MODerate-resolution Imaging Spectroradiometer (MODIS) global LST product is one of the most widely used remotely-sensed LST dataset for SUHI studies [17,27-32]. This study uses MODIS LST 8-day composite imagery (MOD11A2) from 2000 to 2014 for both daytime and nighttime. Although the spatial resolution of MODIS LST imagery $(1000 \mathrm{~m})$ is slightly coarse, a total number of 2766 pixels are evaluated for the entire Phoenix metropolitan area that gives a relatively large sample size. For this study, we restrict the analysis to June as Phoenix has relatively hot, dry, clear, and calm weather conditions for most of the month. It is, therefore, considered an ideal time period for urban LST evaluations [5,33]. Four MODIS LST June images are available-1 June, 9 June, 17 June, and 25 June-during the selected time frame except for 2001, which has only two images available-1 June and 9 June. Hence, a total of 58 pairs of daytime and nighttime LST images are collected for the entire study period.

LULC maps of 2000 and 2014 are used to study the relationship between LULC change and urban LST variations. One is generated using a Landsat 5 Thematic Mapper (TM) image acquired on 14 June 2000 (Figure 2a), and the other is generated using a Landsat 8 Operational Land Imager (OLI) image from 21 June 2014 (Figure 2c). Both images have $30 \mathrm{~m}$ spatial resolution and have been classified into six major LULC classes that include water, impervious surface, vegetation, urban/residential area, open soil, and fallow cropland (Figure 2b,d) using the Iterative Self-Organizing Data Analysis (ISODATA) unsupervised classification algorithm. The "impervious surface" class refers to asphalt and pavements such as parking lots, roads, and highways, whereas the "urban/residential" class represents built-up areas such as large commercial buildings and houses. A minimum of 50 sample points per LULC class were generated using a stratified random sampling approach for the classification accuracy assessment. The assessment was done using Google Earth with the help of local area knowledge. The producer's accuracy, user's accuracy, overall accuracy, and Kappa coefficient are calculated from the error matrix and reported in Table 1 . The overall accuracy of image classification exceeds $85 \%$ for both LULC maps (Table 1 ). 

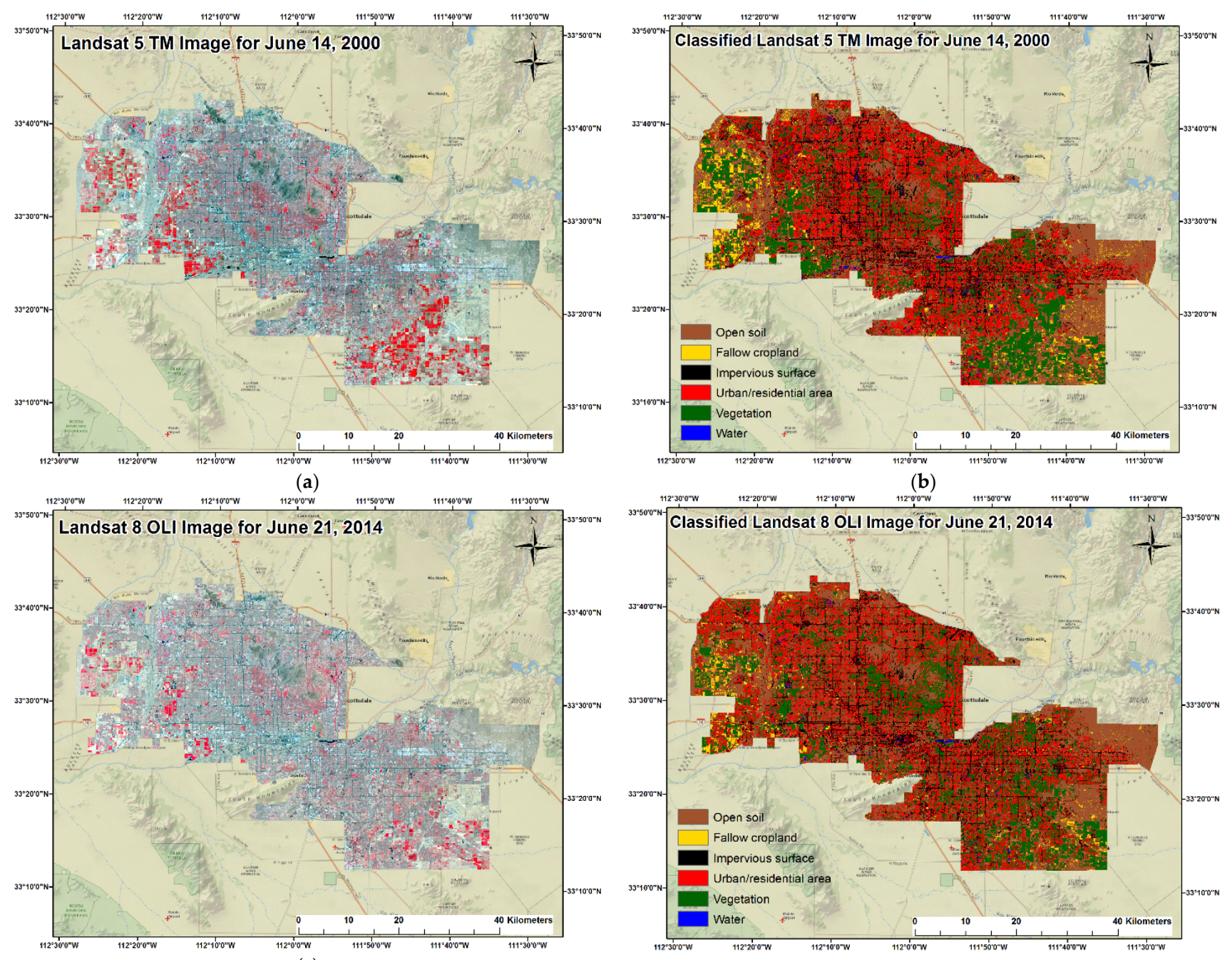

(c)

(d)

Figure 2. Landsat color infrared (CIR) imagery (a and $\mathbf{c}$ ) and classified LULC maps (b and $\mathbf{d})$ for the Phoenix metropolitan area. The six LULC classes include open soil, fallow cropland, impervious surface, urban/residential area, vegetation, and water. 
Table 1. Image classification accuracy assessment.

\begin{tabular}{ccccc}
\hline \multirow{2}{*}{ LULC Types } & \multicolumn{2}{c}{ 2000 Landsat 5 TM Image } & \multicolumn{2}{c}{ 2014 Landsat 8 OLI Image } \\
\cline { 2 - 5 } & Producer's Accuracy & User's Accuracy & Producer's Accuracy & User's Accuracy \\
\hline Open soil & $79 \%$ & $83 \%$ & $77 \%$ & $85 \%$ \\
Fallow cropland & $79 \%$ & $80 \%$ & $84 \%$ & $76 \%$ \\
Urban/Residential & $83 \%$ & $86 \%$ & $79 \%$ & $85 \%$ \\
Vegetation & $100 \%$ & $90 \%$ & $98 \%$ & $94 \%$ \\
Impervious surface & $80 \%$ & $85 \%$ & $78 \%$ & $81 \%$ \\
Water & $97 \%$ & $92 \%$ & $97 \%$ & $89 \%$ \\
\hline Overall accuracy & \multicolumn{2}{c}{} & & $85 \%$ \\
Kappa coefficient & $86 \%$ & & 0.82 \\
\hline
\end{tabular}

\subsection{MODIS LST Image Processing and Data Analysis}

SUHI is normally defined as the LST difference between urban and its surrounding suburban background [34,35], denoted by $\Delta T_{u-r}$ in the subsequent context. Using this definition, a 10-20 km buffer region is first created for the non-urbanized areas surrounding the Phoenix metropolitan boundary in ArcMap software. This buffer is selected because there is no converted natural landscape in this region. In order to avoid confusion and for a fair comparison, mountainous regions and large water bodies within the buffer are manually removed, and only areas that have an elevation that falls within two standard deviations from the mean elevation of the city are retained.

The metropolitan and rural buffer pixels are extracted from the MODIS LST images and pixel values are converted to LST in degrees Celsius $\left({ }^{\circ} \mathrm{C}\right)$ for both daytime and nighttime images. The mean metropolitan and buffer LST images are then calculated by averaging four June LST images for every year (two images for 2001), resulting in 15 daytime and 15 nighttime mean LST images. Finally, the mean LST is calculated for the entire buffer region for every year and subtracted from each Phoenix metropolitan pixel to generate LST difference maps. These maps are named Level-1 products. The pixel values, $\Delta T_{u-r}$, now represent LST differences between the metropolitan and non-urbanized buffer area.

Using the year sequence of 2000 to 2014 as the independent variable and $\Delta T_{u-r}$ as the dependent variable, a time-series trend analysis is then performed using ordinary least square (OLS) regression on every single pixel to examine if $\Delta T_{u-r}$ has significantly changed during the study period. Since this study is designed to examine pixels that have experienced statistically significant changes in $\Delta T_{u-r}$, the regression results that have a $p$-value less than 0.05 are retained for all Level- 1 products. This procedure generates a $p$-value map, an $R$-squared value map, and a regression slope coefficient map for both daytime and nighttime. These maps are named Level-2 products. The detailed LST image processing and data analysis workflow is shown in Figure 3. 


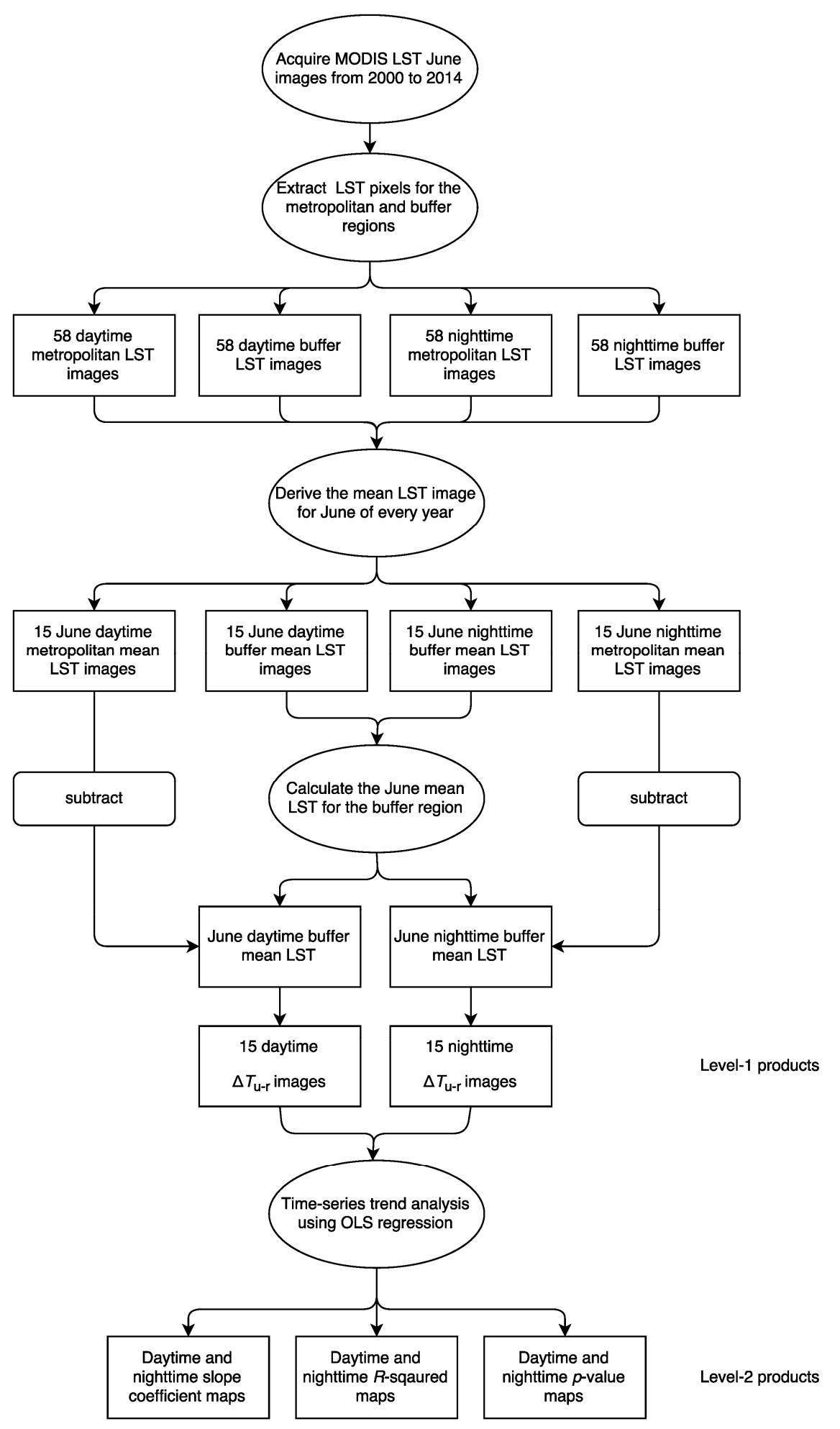

Figure 3. Image processing flowchart.

\subsection{LULC Change Analysis}

This step analyzes LULC change in the Phoenix metropolitan area and its relationship with $\Delta T_{u-r}$ variations between 2000 and 2014. All the pixels in Level-2 products that have experienced statistically significant increases and decreases in $\Delta T_{u-r}$ are separated for both daytime and nighttime images. The separated pixels (1000 m resolution) are used to mask 2000 and 2014 Phoenix LULC maps 
(30 $\mathrm{m}$ resolution) respectively, resulting in eight LULC maps (30 $\mathrm{m}$ resolution) for the specific areas of daytime increasing $\Delta T_{u-r}$; daytime decreasing $\Delta T_{u-r} ;$ nighttime increasing $\Delta T_{u-r} ;$ and nighttime decreasing $\Delta T_{u-r}$ for 2000 and 2014, respectively.

The total area of each LULC class from all the maps generated above are then calculated and compared between 2000 and 2014. The area percentage difference of each LULC class within the same $1000 \mathrm{~m}$ Level-2 product pixel is also calculated. The area percentage difference is positive if there is an area increase, and negative if the area percentage decreases. For example, in 2000 there was $30 \%$ urban/residential area, $40 \%$ open soil, $20 \%$ vegetation, and $10 \%$ impervious surface within one particular $1000 \mathrm{~m}$ Level-2 product pixel. The area percentages became $60 \%$ urban/residential area, $10 \%$ open soil, $10 \%$ vegetation, and $20 \%$ impervious surface in 2014 . The area percentage differences are $+30 \%,-30 \%,-10 \%$, and $+10 \%$ for urban/residential area, open soil, vegetation, and impervious surface, respectively, within that particular Level-2 product pixel. For the analysis of the impact of LULC change on LST variation, the LULC area percentage difference values ( $x$-variable) are then analyzed against the regression slope coefficient values from Level-2 products ( $y$-variable) using Pearson's correlation analysis. The correlation coefficients $(r)$ and $p$-values are reported.

\section{Results}

\subsection{Ordinary Least Squares Regression Results}

The regression results (Figures 4-6) show that the Phoenix metropolitan area has experienced very significant $\Delta T_{u-r}$ changes between 2000 and 2014 for both daytime and nighttime. For the slope coefficients we neglect all the slope values between $\pm 0.143{ }^{\circ} \mathrm{C}$ /year. A slope value between $\pm 0.143{ }^{\circ} \mathrm{C} /$ year approximately represents a mean $\Delta T_{u-r}$ change of less than $2{ }^{\circ} \mathrm{C}$ between 2000 and 2014, which is negligible for SUHI intensity studies. The red pixels have positive slope coefficients representing the areas with increasingly higher LST than the surrounding non-urbanized areas, while the areas that have negative slope coefficients (blue pixels) represent an increasingly lower LST than the non-urbanized areas during the study period (Figure 4). The greater the absolute value of the slope coefficient is, the higher the $\Delta T_{u-r}$ change will be.

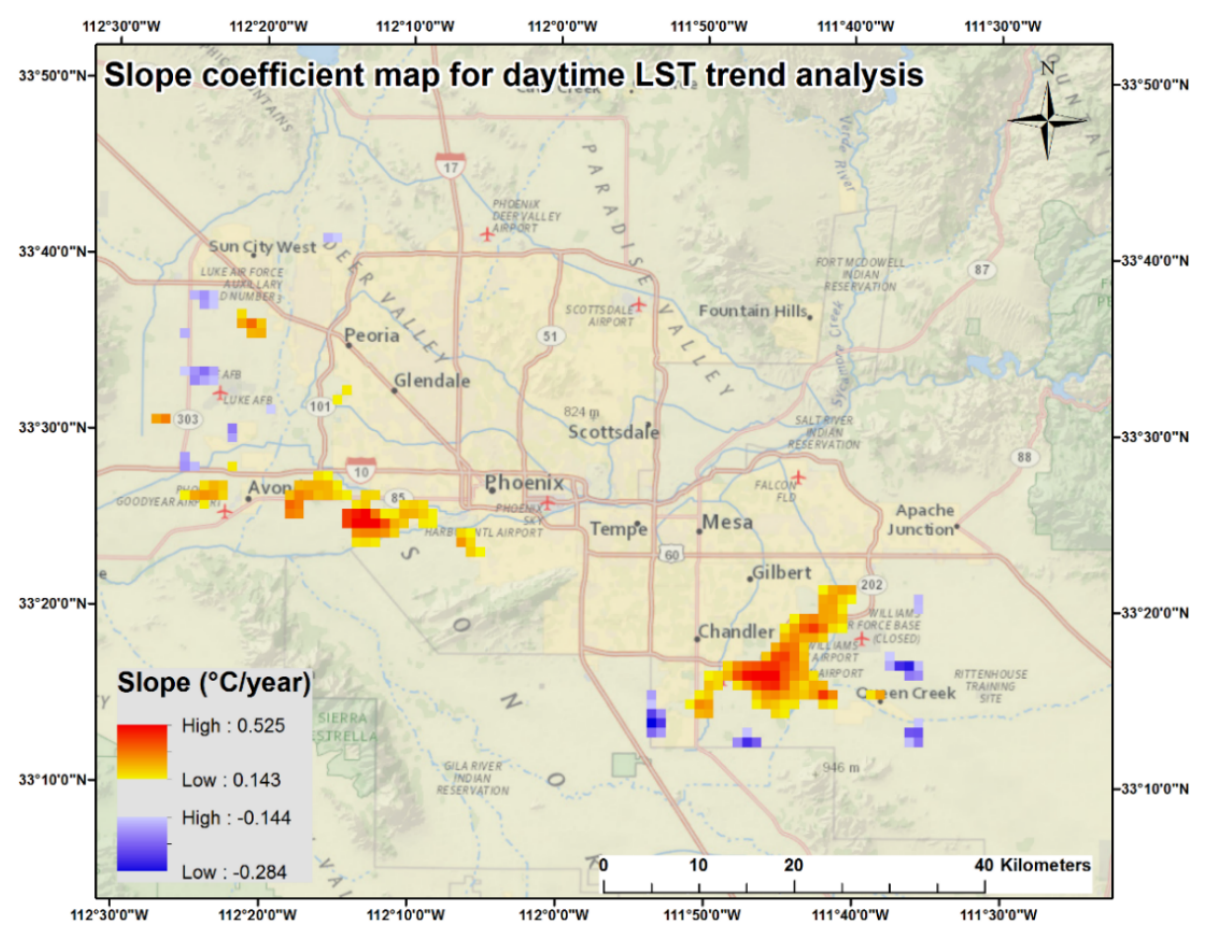

Figure 4. Cont. 


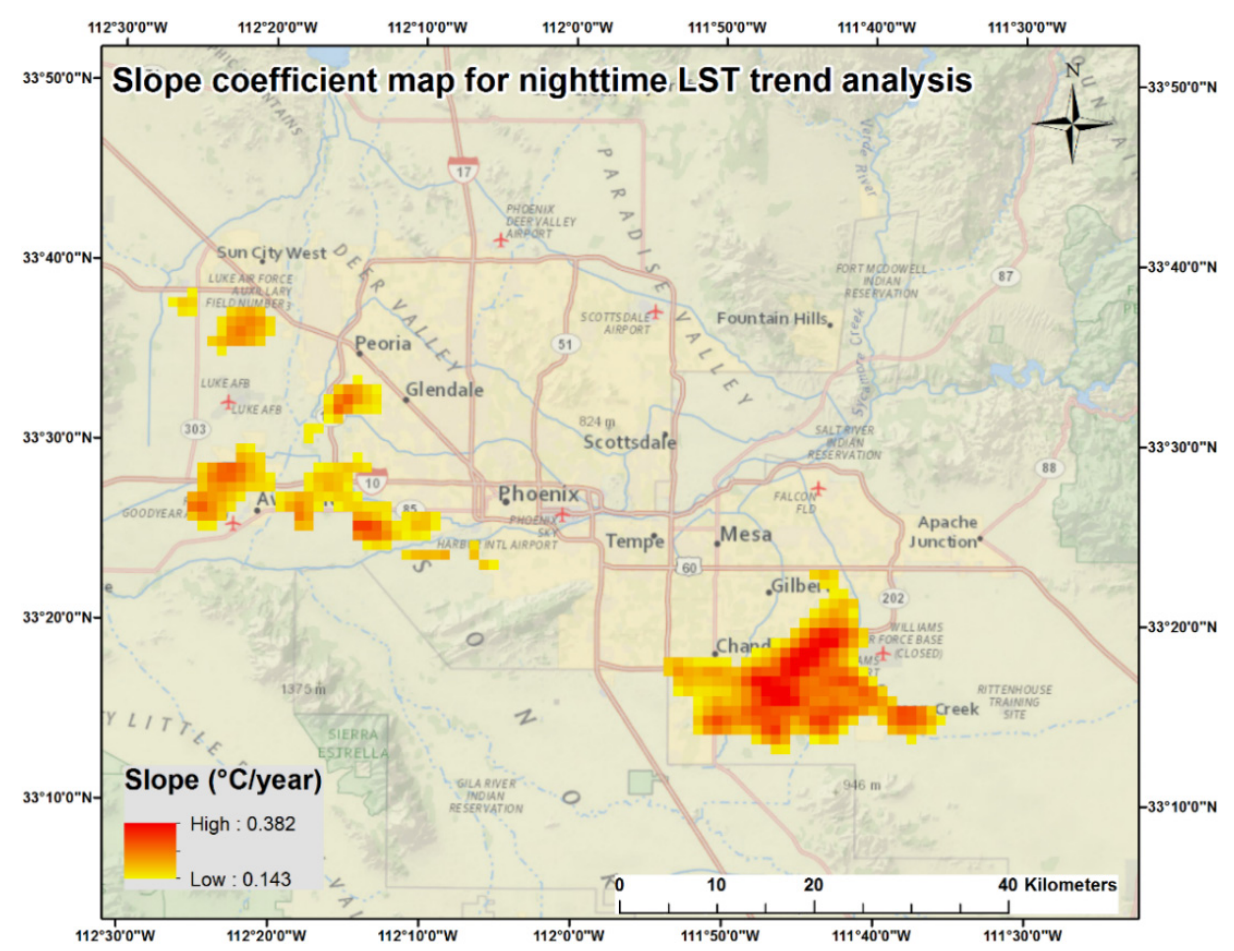

Figure 4. Slope coefficient maps for daytime and nighttime LST trend analysis.

These results indicate that most significant changes of SUHI intensity have taken place on the outskirts of the city with no significant changes observed in existing, developed, urban areas. The areas being continuously cooled during the daytime are all located on the city outskirts and the total area is approximately $47 \mathrm{~km}^{2}$. The largest drop of $\Delta T_{u-r}$ is approximately $4{ }^{\circ} \mathrm{C}$ from 2000 to 2014 . Most increasing daytime $\Delta T_{u-r}$ areas are found in the southeastern (e.g., southeast Chandler) and western (e.g., west Phoenix) parts of metropolitan Phoenix that encompass a total area of $176 \mathrm{~km}^{2}$, which is almost three times larger than the areas being cooled. $\Delta T_{u-r}$ has increased significantly from 2000 to 2014 during the daytime, ranging from $2{ }^{\circ} \mathrm{C}$ to $7.35^{\circ} \mathrm{C}$ with the highest increase of $\Delta T_{u-r}$ found in the western part of Phoenix.

The nighttime images demonstrate a similar spatial distribution pattern, but no significantly decreasing trend was found for nighttime $\Delta T_{u-r}$. In fact, all pixels in the nighttime images show a very significant increase of $\Delta T_{u-r}$ encompassing a total area of $410 \mathrm{~km}^{2}$, which is more than twice as large as the daytime areas. The highest $\Delta T_{u-r}$ increase at night was $5.35^{\circ} \mathrm{C}$ and can be observed mostly in the southeastern part of the Phoenix metropolitan area (e.g., southeast Chandler and south Gilbert).

The $R$-squared (Figure 5) and $p$-value (Figure 6) images show that the regions that have experienced the highest significant changes of $\Delta T_{u-r}$ for the daytime are in the southeast (e.g., southeast Chandler and south Gilbert), west (e.g., west Phoenix), and northwest (e.g., west Surprise and southwest El Mirage). At night, the southeastern (e.g., southeast Chandler and south Gilbert) and western (e.g., west Phoenix and north Goodyear) parts of the metropolitan area have the highest $R^{2}$ values (Figure 5 ) and all pixels are significant at the 0.01 level (Figure 6). The nighttime $\Delta T_{u-r}$ changes are found to be much more significant and the relationships are much stronger than the daytime $\Delta T_{u-r}$. 

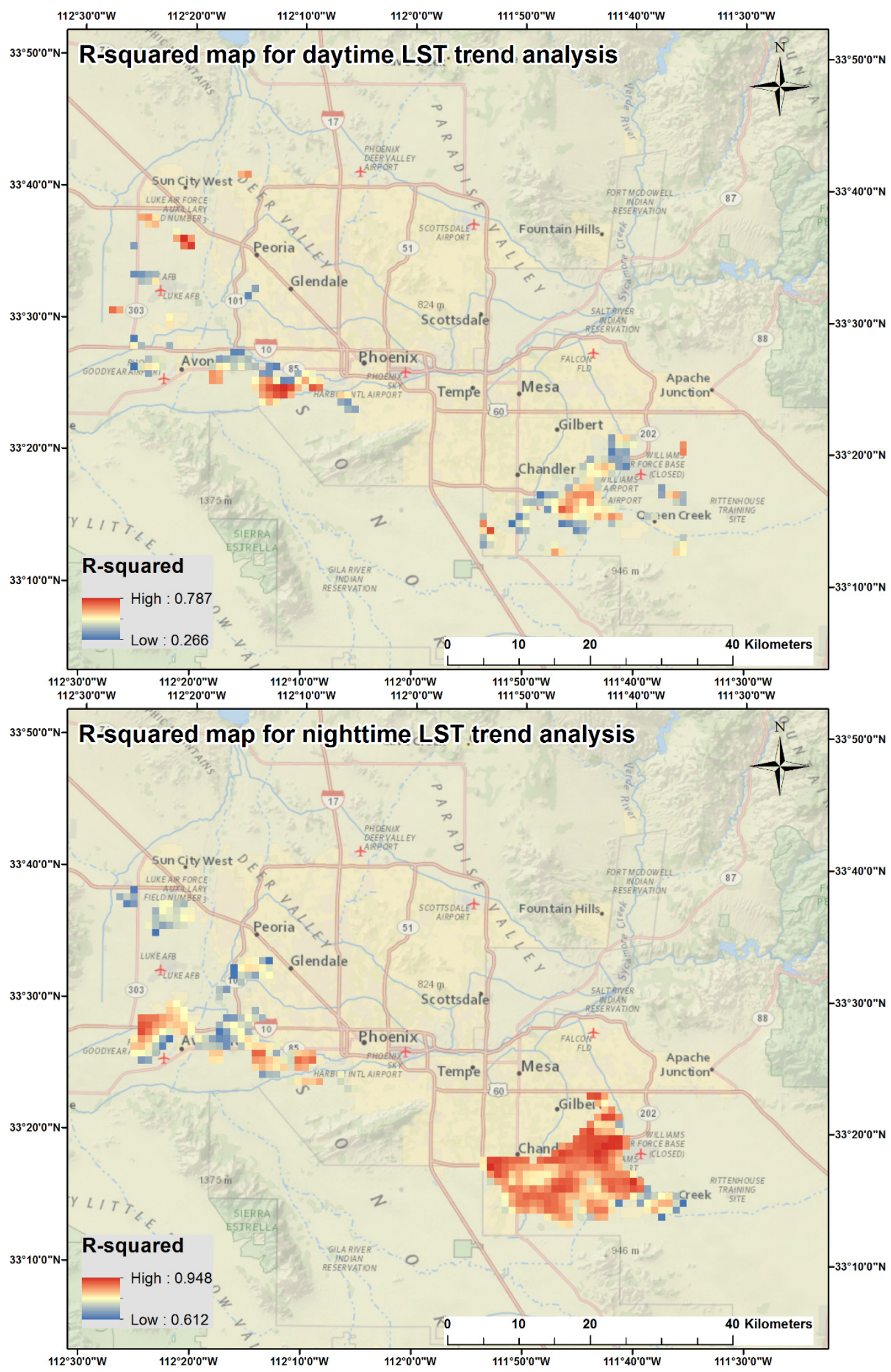

Figure 5. Daytime and nighttime $R$-squared value images. 


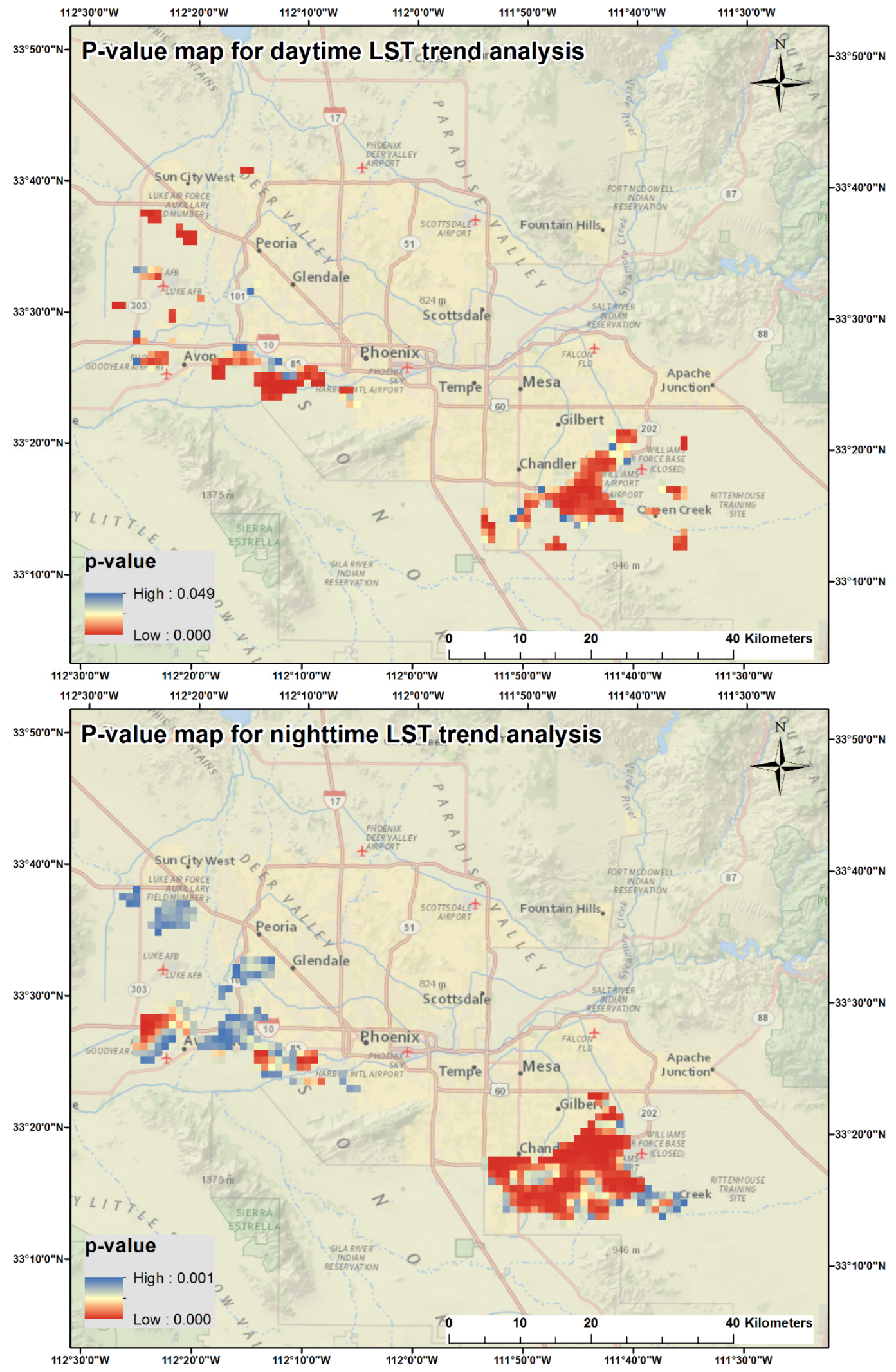

Figure 6. Daytime and nighttime $p$-value images. 


\subsection{LULC Change Analysis Results}

The total area of LULC types for those regions that have experienced significant $\Delta T_{u-r}$ changes for 2000 and 2014 are shown in Figure 7. Note that the urban/residential and impervious surface areas increase dramatically in each scenario, while the areas of water, fallow cropland, and open soil decrease. For the daytime increasing $\Delta T_{u-r}$ regions (Figure 7a), the urban/residential area has increased more than four-fold from $10.58 \mathrm{~km}^{2}$ to $45.57 \mathrm{~km}^{2}$, and the impervious surface area has almost tripled from $14.9 \mathrm{~km}^{2}$ to $41.63 \mathrm{~km}^{2}$. The decrease of vegetation area from $86.03 \mathrm{~km}^{2}$ to $40.85 \mathrm{~km}^{2}$ is the most notable among all the other LULC types. The same LULC change pattern was also found for the regions where $\Delta T_{u-r}$ has increased at night (Figure $7 \mathrm{~b}$ ). In this case, the total area of the urban/residential class has increased from $35.33 \mathrm{~km}^{2}$ to $134.52 \mathrm{~km}^{2}$ and impervious surface area has increased from $35.96 \mathrm{~km}^{2}$ to $89.97 \mathrm{~km}^{2}$, while all the other LULC types, including vegetation, have decreased. This suggests that urbanization is the major LULC change characteristic between 2000 and 2014 for those regions that have experienced increasing $\Delta T_{u-r}$. Figure $7 \mathrm{c}$ shows LULC areas for the regions where daytime $\Delta T_{u-r}$ has significantly decreased. While both the urban/residential and impervious surface areas for these regions increased, vegetation also increased from $10.48 \mathrm{~km}^{2}$ to $16.1 \mathrm{~km}^{2}$. This suggests that vegetation increase can help lower daytime urban surface temperature.

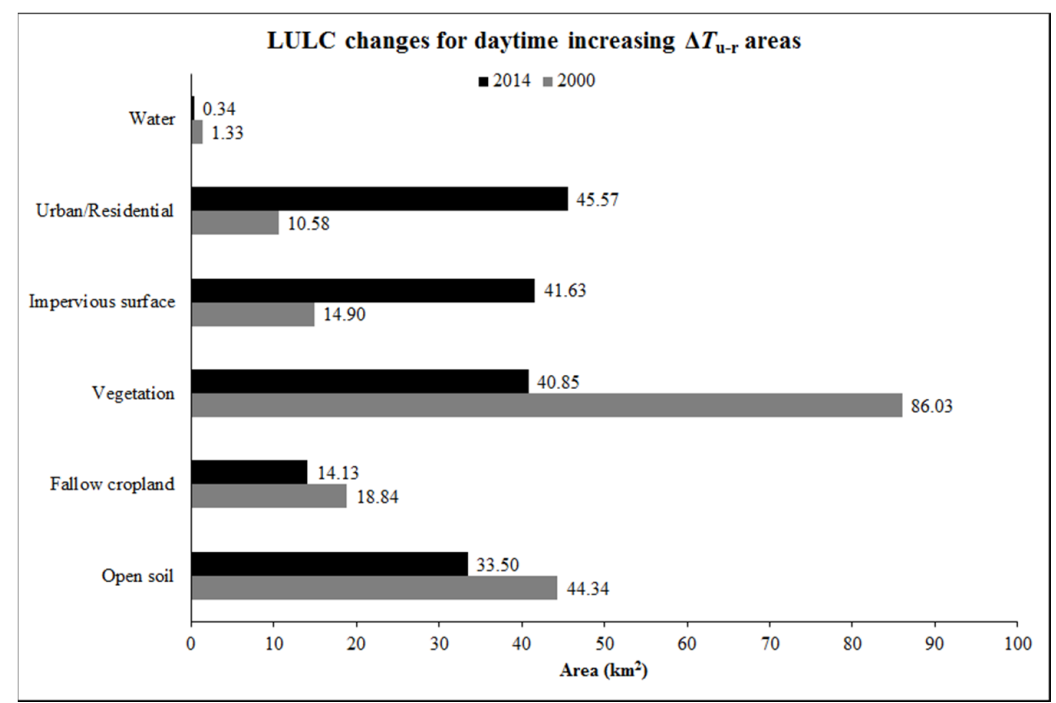

(a)

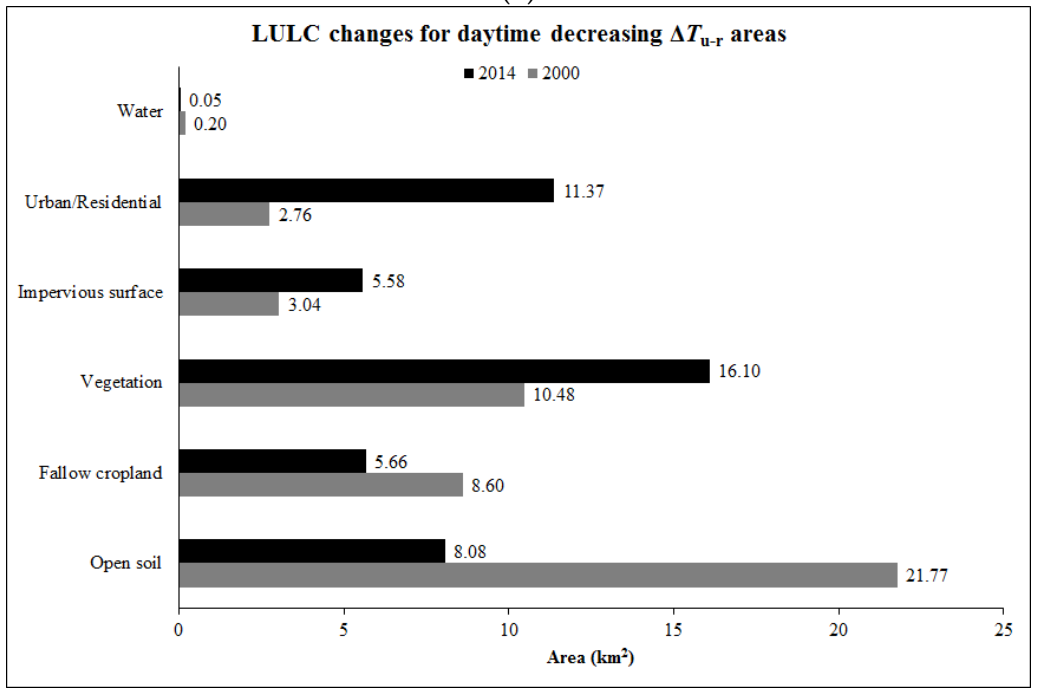

(b)

Figure 7. Cont. 


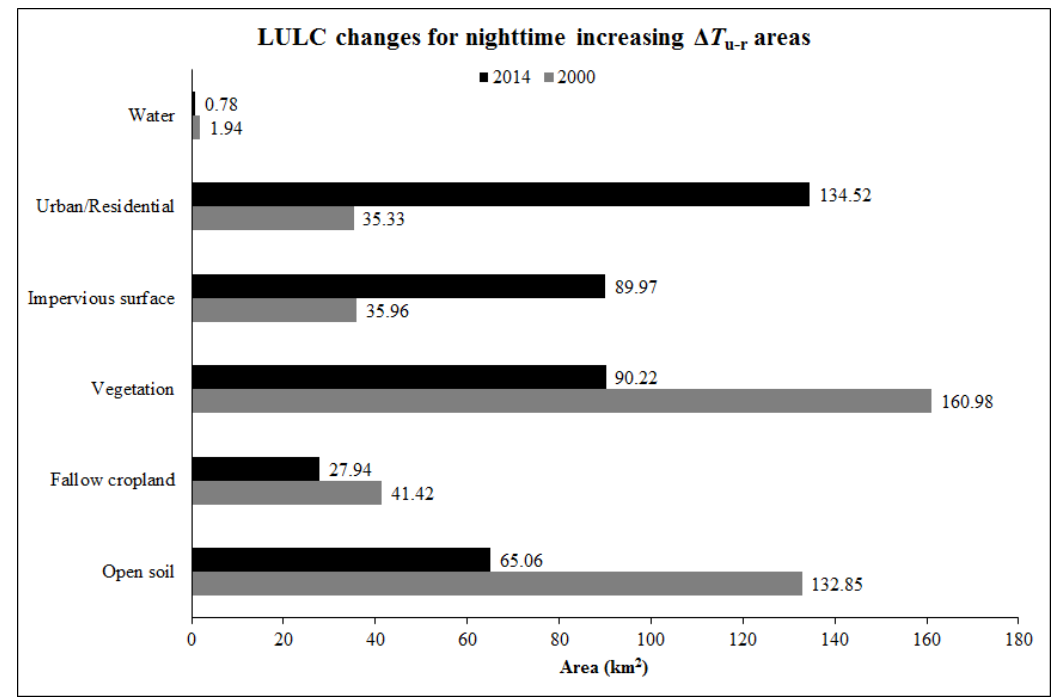

(c)

Figure 7. Area change of each LULC type between 2000 and 2014 for regions that have experienced statistically significant increasing $\Delta T_{u-r}$ for the daytime (a); decreasing $\Delta T_{u-r}$ for the daytime (b); and increasing $\Delta T_{u-r}$ for the nighttime (c). Note: no significant decreasing $\Delta T_{u-r}$ has been observed for the nighttime.

The correlation analysis results (Table 2) further explain how LULC changes influence $\Delta T_{u-r}$ variation and which LULC change has the most significant effect on the variability of the SUHI intensity. Both open soil and impervious surface areas have significant positive correlations $(p<0.05)$ with the regression slope coefficient for both daytime and nighttime, indicating a heating effect contributed to the UHI effect. The correlation between open soil areas and slope coefficient is much weaker for the nighttime scenario $(r=0.1237, p<0.05)$ than the daytime $(r=0.4287, p<0.01)$, while urban $/$ residential areas tend to have a stronger heating effect at night $(r=0.3009, p<0.01)$. Vegetation cover has a highly significant negative correlation with the slope coefficient for both daytime $(r=-0.6087, p<0.01)$ and nighttime $(r=-0.4157, p<0.01)$, which means that the vegetation has a strong cooling effect that can mitigate the UHI effect in Phoenix. In addition, fallow cropland is also found to have a potential cooling effect at night, but the correlation is relatively weak although it is still highly significant $(r=-0.1463, p<0.01)$.

Table 2. Correlation analysis between slope coefficient values from LST trend analysis and LULC change for both daytime and nighttime.

\begin{tabular}{ccccccc}
\hline & $\begin{array}{c}\text { Open } \\
\text { Soil }\end{array}$ & $\begin{array}{c}\text { Fallow } \\
\text { Cropland }\end{array}$ & Urban/Residential & Vegetation & $\begin{array}{c}\text { Impervious } \\
\text { Surface }\end{array}$ & Water \\
\hline Slope & $0.4287^{*}$ & 0.0564 & 0.1136 & $-0.6087^{*}$ & $0.3631^{*}$ & 0.0253 \\
(daytime) & $(0.0000)$ & $(0.4016)$ & $(0.0905)$ & $(0.0000)$ & $(0.0000)$ & $(0.7076)$ \\
\hline Slope & $0.1237^{*}$ & $-0.1463^{*}$ & $0.3009^{*}$ & $-0.4157^{*}$ & $0.3399 *$ & 0.0209 \\
(nighttime) & $(0.0122)$ & $(0.0030)$ & $(0.0000)$ & $(0.0000)$ & $(0.0000)$ & $(0.6729)$ \\
\hline
\end{tabular}

Note: LULC change here means the area percentage difference between 2000 and 2014. See Section 3.3 for details. The $p$-values are in parentheses. The correlation coefficients that are statistically significant at the 0.05 level are marked by an asterisk $\left(^{*}\right)$.

\section{Discussion}

The SUHI intensity in the Phoenix metropolitan area has increased dramatically in the past 15 years. The most significant changes occurred most often on the metropolitan outskirts, with little change observed in existing developed areas, such as downtown Phoenix, Tempe, and Mesa. 
Although LST can be very high in these developed areas, LST changes over time are insignificant because there were no obvious LULC changes.

Although the nighttime SUHI intensity for the entire Phoenix metropolitan area is slightly lower than that of the daytime (Figure 4), the total area that suffers increasing UHI effect is much larger at night. The LST increasing trend is much stronger (Figure 5) and more statistically significant (Figure 6) for the nighttime, resulting in the metropolitan Phoenix area's UHI effect becoming more and more prominent at night.

Urbanization in Phoenix has quickly converted geographic terrains from natural landscapes, such as grasslands, open soil, and undisturbed desert area, and cultivated vegetation, such as croplands, to manmade engineered surfaces and infrastructure. The effect of the built-up environment manifests itself by impacting turbulent transport radiative heat exchange and hydrological processes, especially in urban canopies [36]. Schatz and Kucharik also demonstrated in their paper that the built-up environment was the primary driver of the spatial change in temperature patterns in the urban area [37]. They found that urban environments, together with their dark impervious surfaces and reduced vegetation cover, normally have large heat capacity and high thermal conductivity rates [34,38-42]. This not only causes less incoming solar radiant energy to be reflected, but also less of the energy to be converted to latent heat associated with evaporation and transpiration [43].

Manmade materials, especially dark impervious surfaces, absorb shortwave radiation and store heat during the daytime. They then release longwave radiation slowly at night, heating up the lower atmosphere $[38,40,44]$. The correlation analysis results (Table 2) indicate that it is the percentage increase of impervious surfaces, rather than the urban/residential buildings, that have the highest and most significant positive correlation with the regression slope coefficients. This finding is consistent with some other studies $[11,16]$. In addition, anthropogenic activities also have a great impact on urban climate by generating and releasing heat and water into the atmospheric boundary layer [45-47], by way of fuel burning, air conditioning, automobiles, and machinery, that cannot be quickly dispersed [43]. As rural landscapes are being continuously converted to built-up environments, larger rural areas suffers significant LST increase and UHI effect. All the aforementioned mechanisms explain why most significant increase of $\Delta T_{u-r}$ occurs on the city outskirts but not within the city's developed areas. It also explains why the $\Delta T_{u-r}$ increasing trend is much stronger and a much larger area of SUHI intensity has been observed for the nighttime rather than the daytime.

Vegetation evapotranspiration can lower LST by releasing more latent heat flux but less sensible heat flux from the surface to the atmosphere. Research has reported that normally lower LSTs are found in areas with higher vegetation cover [11], and increasing vegetation cover area is considered an effective mitigation strategy to reduce UHI effects [48-52]. In addition, controlled irrigation of green spaces in cities can help to reduce thermal stress and building energy consumption during hot seasons [53]. Our correlation analysis shows that the increase of vegetation cover has the strongest and most significant negative relationship with the regression slope coefficients (Table 2), indicating that an increase of vegetation cover can lower LST in the urban area.

The reduction of green spaces (Figure 7a,b) in Phoenix has also caused significant increases of $\Delta T_{u-r}$ for both daytime and nighttime (Table 2). By 2014, more than half of the vegetated area has disappeared for the daytime scenario (Figure 7a), and about $44 \%$ of the vegetation cover has been converted for the nighttime scenario (Figure $7 \mathrm{~b}$ ). Conversely, for daytime decreasing $\Delta T_{u-r}$ areas, the vegetation cover area was increased by almost $60 \%$ although the urban/residential area and impervious surface area have also dramatically increased (Figure 7c).

The correlation analysis results (Table 2) also demonstrate that the absolute values of the correlation coefficients for the vegetation cover for both daytime and nighttime scenarios are higher than the urban/residential areas and impervious surfaces. This finding demonstrates that the cooling effect of increased vegetation cover is actually stronger than the heating effect due to urban development and expansion. This is consistent with a previous finding that anthropogenic heat has a smaller effect than albedo and vegetation cover [54]. Therefore, the increased vegetation cover is 
the primary contribution to the decreased $\Delta T_{u-r}$. As shown in the 2014 Landsat image, the most increased vegetated areas are irrigated croplands and golf courses. We, therefore, suggest that planting vegetation could effectively mitigate the UHI effects in a desert city like Phoenix for both daytime and nighttime.

Large water bodies have greater specific heat capacity and they have been found to provide a potential cooling effect during the daytime [55]. Phoenix is a desert city, so large open-air water bodies are very scarce. The lack of variation in open water surfaces, together with potential image classification error, means that there is no statistically significant relationship between the change of water body area and LST variation in this research.

\section{Conclusions}

Phoenix is a subtropical desert city that is also one of the warmest cities in the United States. Excessive heat in the urban area has been a major concern for decades, especially during the summer months. This heat compromises human health and comfort, as well as causes water and energy consumption issues, and poor air quality. This research identified the regions in the Phoenix metropolitan area that have experienced the most significant changes of SUHI intensity from 2000 to 2014 using MODIS LST imagery. The relationship between LULC changes and LST variations has also been studied using classified LULC maps created from Landsat imagery.

For both daytime and nighttime, the regions that have experienced the most significant $\Delta T_{u-r}$ changes between 2000 and 2014 include the southeastern and western parts of the metropolitan area. Regions where $\Delta T_{u-r}$ has decreased are only observed for the daytime and are most often located on outskirts of metropolitan Phoenix. The increase of daytime $\Delta T_{u-r}$ is slightly higher than the nighttime. The areas that have experienced significant increases of SUHI intensity are, however, much larger at night.

Urbanization is the primary cause for increased SUHI intensity during the study period. Despite the dramatic increase of urban/residential and impervious surface areas, some areas have decreasing $\Delta T_{u-r}$ during the daytime due to increased vegetation cover for those areas. This study found that the cooling effect of increased vegetation cover is stronger than the heating effect of urbanization for the Phoenix metropolitan area.

In conclusion, the UHI effect in the metropolitan Phoenix has been gradually exacerbated by the rapid development and expansion of the urban area since 2000. More sustainable landscape planning for future city development becomes more pressing, as Phoenix's rapid population and economic growth continues. Based on the results and findings from this research, we would recommend that increase in vegetation cover, with the trade-off between water and energy carefully studied, can be a potentially effective means to mitigate the UHI effect in those high SUHI intensity areas. It is an easy, low-cost, and feasible way to lower the UHI effect and conserve energy.

In addition, we suggest that urban planners, decision-makers, and city managers formulate new policies and regulations that encourage residential, commercial, and industrial developers to include vegetation, such as trees, shrubs, and grass, when planning new construction. These policies should include setting certain percentages of vegetation cover or numbers of small trees with exact height and crown coverage or shrubs before structures are built. This would prevent the clearing of land for built-up areas that typically leaves no vegetation cover, resulting in large areas of exposed open soils, buildings, and impervious surfaces. The concentration of these manmade surfaces elevates LST dramatically over the long run. Keeping existing vegetation or adding vegetation during construction offsets the heat retained by these surfaces. This is especially true for desert cities. Thus, we believe that this is an emerging issue that policy-makers and city planners need to pay attention to.

Acknowledgments: This research is based upon work supported by the National Science Foundation under grant number BCS-1026865, Central Arizona Phoenix Long-Term Ecological Research (CAP LTER).

Author Contributions: All the authors conceived and designed the study; C.W. collected and processed all the data; C.W. and S.W.M. analyzed the data; C.W. wrote the paper; S.W.M., Z.W., and J.S. helped finalize the paper. 
Conflicts of Interest: The authors declare no conflict of interest.

\section{References}

1. Hansen, J.; Ruedy, R.; Glascoe, J.; Sato, M. GISS analysis of surface temperature change. J. Geophys. Res. 1999, 104, 30997-31022. [CrossRef]

2. Akbari, H.; Pomerantz, M.; Taha, H. Cool surfaces and shade trees to reduce energy use and improve air quality in urban areas. Sol. Energy 2001, 70, 295-310. [CrossRef]

3. Kolokotroni, M.; Ren, X.; Davies, M.; Mavrogianni, A. London's urban heat island: Impact on current and future energy consumption in office buildings. Energy Build. 2012, 47, 302-311. [CrossRef]

4. Guhathakurta, S.; Gober, P. The impact of the Phoenix urban heat island on residential water use. J. Am. Plan. Assoc. 2007, 73, 317-329. [CrossRef]

5. Brazel, A.; Gober, P.; Lee, S.-J.; Grossman-Clarke, S.; Zehnder, J.; Hedquist, B.; Comparri, E. Determinants of changes in the regional urban heat island in metropolitan Phoenix (Arizona, USA) between 1990 and 2004. Clim. Res. 2007, 33, 171-182. [CrossRef]

6. Taha, H.; Kalkstein, L.S.; Sheridan, S.C.; Wong, E. The potential of urban environmental control in alleviating heat-wave health effects in five US regions. In Proceedings of the 16th Conference on Biometeorology and Aerobiology, American Meteorological Society, Vancouver, BC, Canada, 23-27 August 2004.

7. Taha, H.; Douglas, S.; Haney, J. The UAM sensitivity analysis: The 26-28 August 1987 oxidant episode. In Analysis of Energy Efficiency and Air Quality in the South Coast Air Basin-Phase II; Taha, H., Ed.; Lawrence Berkeley Laboratory: Berkeley, CA, USA, 1994; Chapter 1.

8. Filleul, L.; Cassadou, S.; Médina, S.; Fabres, P.; Lefranc, A.; Eilstein, D.; Le Tertre, A.; Pascal, L.; Chardon, B.; Blanchard, M.; et al. The relation between temperature, ozone, and mortality in nine French cities during the heat wave of 2003. Environ. Health Perspect. 2006, 114, 1344-1347. [CrossRef]

9. Balling, R.C., Jr.; Brazil, S.W. Time and space characteristics of the Phoenix urban heat island. J. Ariz.-Nev. Acad. Sci. 1987, 21, 75-81.

10. Lee, T.-W.; Lee, J.Y.; Wang, Z.-H. Scaling of the urban heat island intensity using time-dependent energy balance. Urban Clim. 2012, 2, 16-24. [CrossRef]

11. Yuan, F.; Bauer, M.E. Comparison of impervious surface area and normalized difference vegetation index as indicators of surface urban heat island effects in Landsat imagery. Remote Sens. Environ. 2007, 106, 375-386. [CrossRef]

12. Chen, X.-L.; Zhao, H.-M.; Li, P.-X.; Yin, Z.-Y. Remote sensing image-based analysis of the relationship between urban heat island and land use/cover changes. Remote Sens. Environ. 2006, 104, 133-146. [CrossRef]

13. Kato, S.; Yamaguchi, Y. Analysis of urban heat-island effect using ASTER and ETM+ data: Separation of anthropogenic heat discharge and natural heat radiation from sensible heat flux. Remote Sens. Environ. 2005, 99, 44-54. [CrossRef]

14. Nichol, J.E.; Fung, W.Y.; Lam, K.; Wong, M.S. Urban head island diagnosis using ASTER satellite images and "in situ" air temperature. Atmos. Res. 2009, 94, 276-284. [CrossRef]

15. Liu, L.; Zhang, Y. Urban heat island analysis using the Landsat TM data and ASTER data: A case study in Hong Kong. Remote Sens. 2011, 3, 1535-1552. [CrossRef]

16. Myint, S.W.; Wentz, E.A.; Brazel, A.J.; Quattrochi, D.A. The impact of distinct anthropogenic and vegetation features on urban warming. Landsc. Ecol. 2013, 28, 959-978. [CrossRef]

17. Imhoff, M.L.; Zhang, P.; Wolfe, R.E.; Bounoua, L. Remote sensing of the urban heat island effect across biomes in the continental USA. Remote Sens. Environ. 2010, 114, 504-513. [CrossRef]

18. Zheng, B.; Myint, S.W.; Fan, C. Spatial configuration of anthropogenic land cover impacts on urban warming. Landsc. Urban Plan. 2014, 130, 104-111. [CrossRef]

19. Gober, P.; Brazil, A.; Quay, R.; Myint, S.; Grossman-Clarke, S.; Miller, A.; Rossi, S. Using watered landscape to manipulate urban heat island effects: How much water will it take to cool Phoenix? J. Am. Plan. Assoc. 2009, 76, 109-121. [CrossRef]

20. Rossi, F.; Pisello, A.L.; Nicolini, A.; Filipponi, M.; Palombo, M. Analysis of retro-reflective surfaces for urban heat island mitigation: A new analytical model. Appl. Energy 2014, 114, 621-631. [CrossRef]

21. Santamouris, M.; Synnefa, A.; Karlessi, T. Using advanced cool materials in the urban built environment to mitigate heat islands and improve thermal comfort conditions. Sol. Energy 2011, 85, 3085-3102. [CrossRef] 
22. Uemoto, K.L.; Sato, N.M.N.; John, V.M. Estimating thermal performance of cool colored paints. Energy Build. 2010, 42, 17-22. [CrossRef]

23. Jo, J.H.; Carlson, J.D.; Golden, J.S.; Bryan, H. An integrated empirical and modeling methodology for analyzing solar reflective roof technologies on commercial buildings. Build. Environ. 2010, 45, 453-460. [CrossRef]

24. Yang, J.; Wang, Z.-H.; Kaloush, K. E. Environmental impacts on reflective materials: Is high albedo a "silver bullet" for mitigating urban heat island? Renew. Sustain. Energy Rev. 2015, 47, 830-843. [CrossRef]

25. U.S. Census Bureau. Available online: http://www.census.gov/popest/data/metro/totals/2013/index.html (accessed on 29 January 2016).

26. U.S. Climate Data. Available online: http://www.usclimatedata.com/climate/phoenix/arizona/ united-states/usaz0166 (accessed on 29 January 2016).

27. Peng, S.; Piao, S.; Ciais, P.; Friedlingstein, P.; Ottle, C.; Bréon, F.-M.; Nan, H.; Zhou, L.; Myneni, R.B. Surface Urban Heat Island across 419 Global Big Cities. Environ. Sci. Technol. 2012, 46, 696-703. [CrossRef] [PubMed]

28. Schwarz, N.; Lautenbach, S.; Seppelt, R. Exploring indicators for quantifying surface urban heat islands of European cities with MODIS land surface temperatures. Remote Sens. Environ. 2011, 115, 3175-3186. [CrossRef]

29. Tomlinson, C.J.; Chapman, L.; Thornes, J.E.; Baker, C.J. Derivation of Birmingham's summer surface urban heat island from MODIS satellite images. Int. J. Climatol. 2010, 32, 214-224. [CrossRef]

30. Rajasekar, U.; Weng, Q. Urban heat island monitoring and analysis using a non-parametric model: A case study of Indianapolis. ISPRS J. Photogramm. Remote Sens. 2009, 64, 86-96. [CrossRef]

31. Cheval, S.; Dumitrescu, A. The July urban heat island of Bucharest as derived from MODIS images. Theor. Appl. Climatol. 2009, 96, 145-153. [CrossRef]

32. Tran, H.; Uchihama, D.; Ochi, S.; Yasuoka, Y. Assessment with satellite data of the urban heat island effects in Asian mega cities. Int. J. Appl. Earth Obs. Geoinform. 2006, 8, 34-48. [CrossRef]

33. Brazel, A.J.; Selover, N.; Vose, R.; Heisler, G. Tale of two climates-Baltimore and Phoenix urban LTER sites. Clim. Res. 2000, 15, 123-135. [CrossRef]

34. Oke, T.R. The heat island of the urban boundary layer: Characteristics, causes and effects. In Wind Climate in Cities; Cermak, J.E., Davenport, A.G., Plate, E.J., Viegas, D.X., Eds.; Kluwer Academic: Dordrecht, The Netherlands, 1995; pp. 81-107.

35. Steward, I.D.; Oke, T.R. Local climate zones for urban temperature studies. Bull. Am. Meteorol. Soc. 2012, 93, 1879-1900. [CrossRef]

36. Wang, Z.-H.; Bou-Zeid, E.; Smith, J.A. A coupled energy transport and hydrological model for urban canopies with evaluation using a wireless sensor network. Q. J. R. Meteorol. Soc. 2013, 139, 1643-1657. [CrossRef]

37. Schatz, J.; Kucharik, C.J. Seasonality of the urban heat island effect in Madison, Wisconsin. J. Appl. Meteorol. Clim. 2014, 53, 2371-2386. [CrossRef]

38. Oke, T.R. The energetic basis of the urban heat island. Q. J. R. Meteorol. Soc. 1982, 108, 1-24. [CrossRef]

39. Weng, Q. A remote sensing GIS evaluation of urban expansion and its impact on surface temperature in the Zhujiang Delta, China. Int. J. Remote Sens. 2001, 22, 1999-2014.

40. Bouyer, J.; Musy, M.; Huang, Y.; Athamena, K. Mitigating urban heat island effect by urban design: Forms and materials. In Proceedings of the Fifth Urban Research Symposium 2009, World Bank: Cities and Climate Change: Responding to an Urgent Agenda, Marseille, France, 28-29 June 2009; pp. 1-15.

41. Lu, J.; Li, C.; Yu, C.; Jin, M.; Dong, S. Regression analysis of the relationship between urban heat island effect and urban canopy characteristics in a mountainous city, Chongqing. Indoor Built Environ. 2012, 21, 821-836. [CrossRef]

42. Song, J.; Wang, Z.-H. Interfacing the urban land-atmosphere system through coupled urban canopy and atmospheric models. Bound. Layer Meteorol. 2015, 154, 427-448. [CrossRef]

43. Golden, J.S. The built environment induced urban heat island effect in rapidly urbanizing arid regions-A sustainable urban engineering complexity. Environ. Sci. 2004, 1, 321-349. [CrossRef]

44. Mills, G. Urban climatology and urban design. In Proceedings of the 15th ICB \& ICUC, Sydney, Australia, 8-12 November 1999.

45. Bohnenstengel, S.I.; Evans, S.; Clark, P.A.; Belcher, S.E. Simulations of the Landon urban heat island. Q. J. R. Meteorol. Soc. 2011, 137, 1625-1640. [CrossRef] 
46. Pal, S.; Xueref-Remy, I.; Ammoura, L.; Chazette, P.; Gibert, F.; Royer, P.; Dieudonné, E.; Dupont, J.-C.; Haeffelin, M.; Lac, C.; et al. Spatio-temporal variability of the atmospheric boundary layer depth over the Paris agglomeration: An assessment of the impact of the urban heat island intensity. Atmos. Environ. 2012, 63, 261-275. [CrossRef]

47. Lac, C.; Donnelly, R.P.; Masson, V.; Pal, S.; Riette, S.; Donier, S.; Queguiner, S.; Tanguy, G.; Ammoura, L.; Xueref-Remy, I. $\mathrm{CO}_{2}$ dispersion modelling over Paris region within the $\mathrm{CO}_{2}$-MEGAPARIS project. Atmos. Chem. Phys. 2013, 13, 4941-4961. [CrossRef]

48. Rosenfeld, A.H.; Akbari, H.; Bretz, S.; Fishman, B.L.; Kurn, D.M.; Sailor, D.; Taha, H. Mitigation of urban heat islands: Materials, utility programs, updates. Energy Build. 1995, 22, 255-265. [CrossRef]

49. Ca, V.T.; Asaeda, T.; Abu, E.M. Reductions in air-conditioning energy caused by a nearby park. Energy Build. 1998, 29, 83-92. [CrossRef]

50. Ashie, Y.; Thanh, V.C.; Asaeda, T. Building canopy model for the analysis of urban climate. J. Wind Eng. Ind. Aerod. 1999, 81, 237-248. [CrossRef]

51. Tong, H.; Walton, A.; Sang, J.; Chan, J.C.L. Numerical simulation of the urban boundary layer over the complex terrain of Hong Kong. Atmos. Environ. 2005, 39, 3549-3563. [CrossRef]

52. Yu, C.; Hien, W.N. Thermal benefits of city parks. Energy Build. 2006, 38, 105-120. [CrossRef]

53. Yang, J.; Wang, Z.-H. Optimizing urban irrigation schemes for the trade-off between energy and water consumption. Energy Build. 2015, 107, 335-344. [CrossRef]

54. Taha, H. Urban climates and heat islands: Albedo, evapotranspiration, and anthropogenic heat. Energy Build. 1997, 25, 99-103. [CrossRef]

55. Lo, C.P.; Quattrochi, D.A.; Luvall, J.C. Application of high-resolution thermal infrared remote sensing and GIS to assess the urban heat island effect. Int. J. Remote Sens. 1997, 18, 287-304. [CrossRef]

(C) 2016 by the authors; licensee MDPI, Basel, Switzerland. This article is an open access article distributed under the terms and conditions of the Creative Commons by Attribution (CC-BY) license (http:/ / creativecommons.org/licenses/by/4.0/). 